Article

\title{
Ecosystem Service Changes and Livelihood Impacts in the Maguri-Motapung Wetlands of Assam, India
}

\author{
Laxmi D. Bhatta ${ }^{1, *}$, Sunita Chaudhary ${ }^{2}$, Anju Pandit ${ }^{1}$, Himlal Baral ${ }^{3,4}$, Partha J. Das ${ }^{5}$ \\ and Nigel E. Stork ${ }^{6}$ \\ 1 International Centre for Integrated Mountain Development (ICIMOD), Post Box 3226, 44703 Kathmandu, \\ Nepal; anju.pandit@icimod.org \\ 2 Department of Geography and Planning, Macquarie University, Sydney, NSW 2109, Australia; \\ sunita.chaudhary@students.mq.edu.au \\ 3 Centre for International Forestry Research (CIFOR), P.O. Box 0113, BOCBD, Bogor 16000, Indonesia; \\ h.baral@cgiar.org or baral.h@unimelb.edu.au \\ 4 School of Ecosystem and Forest Sciences, The University of Melbourne, Carlton, VIC 3010, Australia \\ 5 Aaranyak, Beltola, Guwahati-781 028, Assam, India; partha@aaranyak.org \\ 6 Environmental Futures Research Institute, Griffith School of Environment, Griffith University, \\ 170 Kessels Road, Nathan, Brisbane, QLD 4111, Australia; nigel.stork@griffith.edu.au \\ * Correspondence: laxmi.bhatta@icimod.org; Tel.: +977-1-5003222; Fax: +977-1-5003277
}

Academic Editors: Andrew Millington and Peter Verburg

Received: 29 September 2015; Accepted: 23 May 2016; Published: 3 June 2016

\begin{abstract}
Wetlands provide a diverse range of ecosystem services supporting livelihoods of many people. Despite their value, wetlands are continuously being degraded. There is scant information on individual wetlands, people's dependency and their exploitation at a local scale. We therefore assessed wetland ecosystem services, the drivers of change and impacts of those drivers on ecosystem services and people's dependency through a case study of the Maguri-Motapung Beel wetlands of Assam, India. Both qualitative and quantitative data were collected through household surveys, focus group discussions, key informant interviews and community workshops. The analyses showed a total of 29 ecosystem services, and high dependency on these with five out of seven livelihood strategies sourced from ecosystem services. Over-exploitation of wetland resources and siltation were reported as the major direct drivers of change with impacts on both ecosystem services and people's livelihoods. Drastic decreases in availability of thatch, fish stocks, fodder and tourism were observed. This suggests that there is an urgent need for a comprehensive participatory management plan. Actions are needed to maintain the Maguri-Motapung Beel wetlands and the flow of services in order to sustain people's livelihoods in the area. With an estimated $50 \%$ global loss of wetlands in the last century and the loss of 5,000 square kilometers a year in Asia alone, the loss of ecosystem services and livelihood impacts shown in our study may be typical of what is occurring in the region and perhaps globally.
\end{abstract}

Keywords: wetland; ecosystem services; drivers of change; dependency; impacts

\section{Introduction}

Wetlands cover $5-10 \%$ of Earth's terrestrial surface [1] and are defined as "the areas of marsh, fen, peat land or water, whether natural or artificial, permanent or temporary, with water that is static or flowing, fresh, brackish or salt, including areas of marine water, the depth of which at low tide does not exceed six meters" [2]. As a transitional ecosystem between terrestrial and aquatic ecosystems, wetlands support high biodiversity [3,4] and are essential to the health of both aquatic and terrestrial life forms [1]. With their specific hydrological functions, they control floods by slowing down water movement, reducing water velocity and sedimentation [5], and promote aquifer replenishment [6]. 
Wetlands are also important for human society $[7,8]$ as they provide a diverse range of ecosystem services [2]. In particular, the provision of food, water and livelihood security to the people living in and around them is widely recognized [8-10]. Their global economic values were calculated to be about USD 70 billion per year [11]. However, wetlands are under constant degradation in many countries [1,12] despite increased understanding of their values [13]. Global loss of wetlands has been estimated to be about 50\% since 1900 [14], resulting in significant impacts on ecosystem services, biodiversity and livelihoods of people [15]. In Asia alone, about 5,000 square kilometres of wetlands are lost annually [16].

The concept of ecosystem services is becoming influential in environmental research and policy [17,18]. Applied from coastal [19] to mountain ecosystems [20-22], ecosystem services are now prioritized for conservation $[23,24]$, landscape level planning and management $[23,25,26]$ and decision-making [27]. Ecosystem services are widely evaluated for wetlands, showing people's dependency on ecosystem services, the value of wetlands, and the drivers of change affecting wetland functions [28]. However, assessing and mapping of community perceptions of ecosystem services has only recently emerged [21,24,29]. Millennium Ecosystem Assessment (2005) (MEA) demonstrated the strong links between ecosystem services and the livelihoods of people and how the decline of ecosystem services across biomes has resulted in changes to peoples' livelihoods. We use the MEA framework as a basis for our study, where we examine changes in wetlands and the consequent impacts on people. In particular, we use the separation of ecosystem services into provisioning (= products obtained from ecosystems), regulating (= benefits obtained from the regulation of ecosystem processes), cultural (= nonmaterial benefits people obtain from ecosystems through spiritual enrichment, cognitive development, reflection, recreation, and aesthetic experiences), and supporting (= those that are necessary for the production of all other ecosystem services) [13].

Interest in wetlands of south Asia is increasing because of the diversity of wetlands across a range of altitudes from coastal regions to the Himalayas and their importance in supporting high biodiversity [30]. In India, the total area under wetlands is estimated to be 15.3 million ha, covering about $5 \%$ of the country and supporting $20 \%$ of its known biodiversity [31-34]. Of this, about $69 \%$ are inland wetlands, $27 \%$ coastal, and $4 \%$ are other kinds of wetlands $(<2.25 \mathrm{ha})$ [32]. These wetlands are also important centers of social, cultural and recreational activity with large numbers of people living in and around them being totally dependent on their resources for their livelihoods $[35,36]$. However, increasing concern has been expressed over the continuing degradation of India's wetlands. Anthropogenic activities such as urban development, agricultural expansion, industrial pollution and other threats such as global climate change have caused the significant loss of wetlands $[31,37,38]$ estimated a $38 \%$ decrease in Indian wetlands since 2000. About $70 \%$ of the total area under wetlands in India is under paddy cultivation [39].

Information on individual wetlands and their exploitation at the local level is very limited [36]. Precise information about the values and drivers of changes is required for the conservation and sustainable use of wetlands [40]. Knowledge on wetland ecosystem services, drivers of change and subsequent impacts specific to regions or areas of concern is essential for ensuring wise use, conservation and sustainable development [41-43]. Assessment of wetland ecosystems on a temporal scale and particularly at the local level helps with monitoring changes, providing vital information for natural resource planning and management [33]. For conservation planning and management, there is a clear need for a more detailed understanding of the ecosystem services provided by wetlands, and of the threats they are exposed to [13].

This study, therefore, aims to identify and assess ecosystem services, the drivers of change of wetland ecosystem and the impacts of those changes on people's livelihoods, using a case study of the Maguri-Motapung Beel wetland of Assam, India. Although we recognize that wetland areas are not all the same, our objective is to show through this case study the scale of changes to ecosystem services and livelihoods that wetlands in the region and perhaps globally may be experiencing and hence the potential consequences for local people. 


\section{Methods}

\subsection{Study Area}

The Maguri-Motapung Beel wetland was selected for this case study because of its ecological significance, values for society and the threats it is currently facing. The wetland is lake-like with static water formed by inundation of low-lying lands during flooding, with water trapped even after floodwaters recede [44]. Situated between $27^{\circ} 34^{\prime} 49.92^{\prime \prime} \mathrm{N}$ to $27^{\circ} 34^{\prime} 34.98^{\prime \prime} \mathrm{N}$ and $95^{\circ} 21^{\prime} 37.68^{\prime \prime} \mathrm{E}$ to $95^{\circ} 24^{\prime} 11.39^{\prime \prime} \mathrm{E}$, this wetland is one of the most seriously threatened floodplain-wetlands [45] in the District of Tinsukia of Assam, India, with one of the major threats being over-exploitation [44]. Dibru-Saikhowa National Park (DSNP) is situated to the south while the six villages, Baghjan gaon, Purani Motapung, Rangara Te Natungaon, Gotong Gaon, Na-Motapung gaon and Dhalakhat gaon are situated on its east, west and north sides (Figure 1). The population of those villages, according to the 2011 National Census Report, is 10,688, and was only 10,368 in 2001 (Table 1). The population of Maguri-Motapung Beel wetland and surroundings is primarily dominated by ethnic communities such as Moran, Motok, Koch with an average households size of 4.9 . The literacy rate is $62 \%$ with less than $5 \%$ of the population above higher secondary level education. The average landholding is about half a hectare.

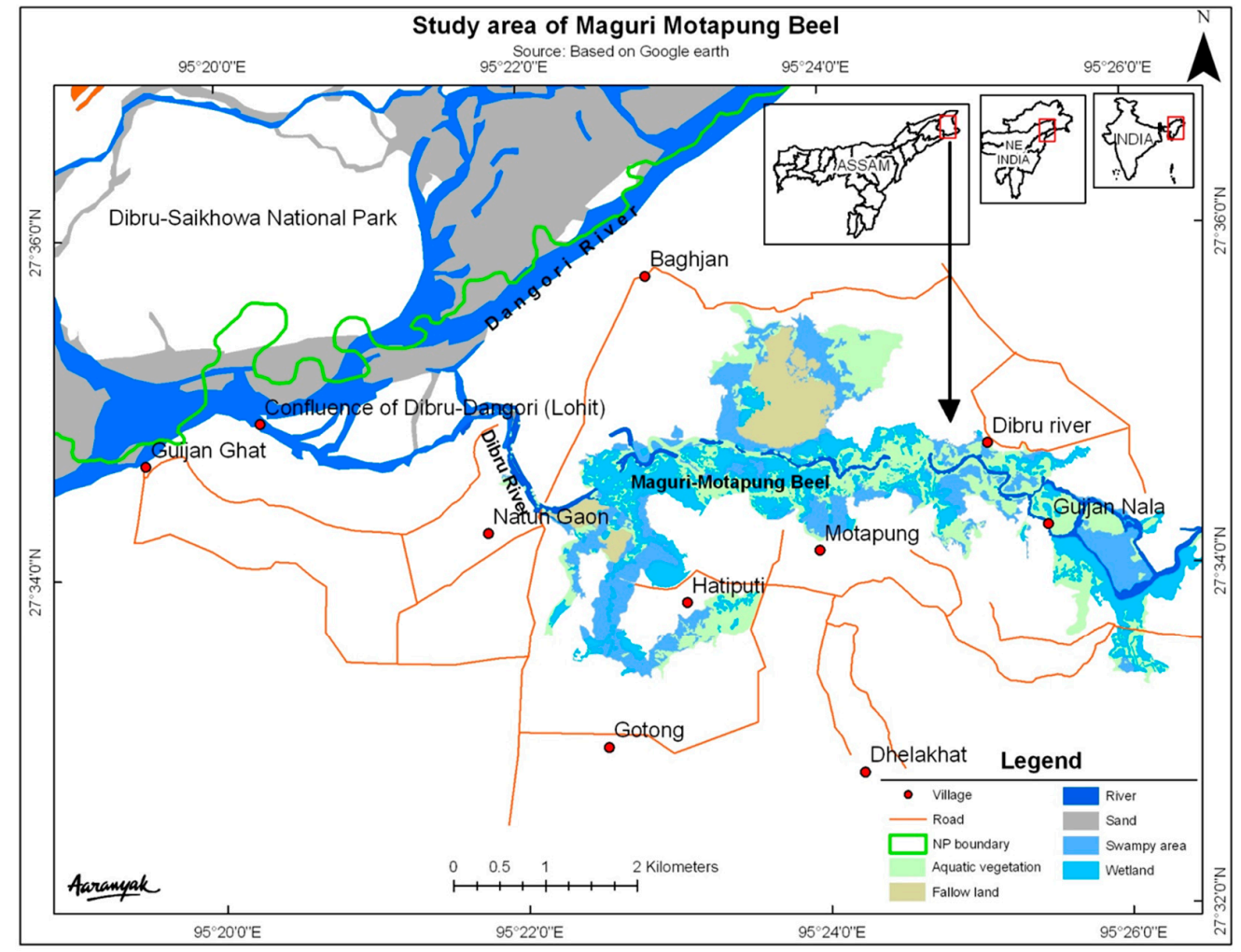

Figure 1. Study area of Maguri-Motapung Beel wetland.

The study wetland lies in the Indo-Burma global biodiversity hotspot [46] in close proximity to the Eastern Himalayas and acts as both a lentic and lotic system throughout the year [44]. It is connected to the Dibru River and is characterized by swamp forests, semi-evergreen forests, deciduous forests and patches of wet evergreen forests. The area has an annual rainfall of 2,300 $\mathrm{mm}$ to 3,800 $\mathrm{mm}$, with temperatures ranging from $7^{\circ} \mathrm{C}$ to $35^{\circ} \mathrm{C}$. The maximum elevation and minimum elevation are 126 meters and 110 meters, respectively, above mean sea level. The wetland is ecologically important with 36 species of mammals, 500 species of birds, 105 species of butterflies, and 108 species of fish [47]. The critically endangered Gangetic River Dolphin (Platanista gangetica gangetica) has been reported in the wetland when flooded [48]. The area has also been declared as an Important Bird Area (IBA) 
and Endemic Bird Area [49] with some rare and highly range-restricted species including Jerdon's Babbler (Chrysomma altirostre), Marsh Babbler (Pellorneum palustre), Swamp Prinia (Prinia cinerascens) and Black breasted Parrotbill (Paradoxornis flavirostris). The wetland is especially rich in fish species, supporting the livelihoods of people living nearby the area. Some of the major fish species include Anguilla bengalensis, Notopterus notopterus and Cirrhinius mrigala.

Table 1. Total number of households and population in 2001 and 2011 in surrounding villages of the study wetland. This shows that there has been little overall change in the population during this period. Source: National Census Report 2001 and 2011, available at http:/ / www.censusindia.gov.in (cited on 24 August 2015).

\begin{tabular}{lccccc}
\hline \multirow{2}{*}{ Name of Village } & \multicolumn{2}{c}{ No. of Households } & \multicolumn{2}{c}{ Population } & \multirow{2}{*}{ Change in Population } \\
\cline { 2 - 5 } & $\mathbf{2 0 0 1}$ & $\mathbf{2 0 1 1}$ & $\mathbf{2 0 0 1}$ & $\mathbf{2 0 1 1}$ & \\
\hline Baghjan gaon & 701 & 872 & 3648 & 4488 & 840 \\
Purani Motapung & 349 & 403 & 2033 & 2127 & 94 \\
Rangara Te Natungaon & 220 & 258 & 1227 & 1348 & 121 \\
Gotong Gaon & 247 & 152 & 1391 & 796 & 595 \\
Na-Motapung Gaon & 210 & 195 & 1156 & 1001 & 155 \\
Dhalakhat Gaon & 184 & 177 & 913 & 928 & 15 \\
Total & 1911 & 2057 & 10368 & 10688 & 320 \\
\hline
\end{tabular}

\subsection{Methodology}

We adopted a case study approach, and data were collected using both qualitative and quantitative methods. We adopted similar strategies to Sandhu and Sandhu [50] to identify how people's livelihoods were dependent on ecosystem services.

\subsubsection{Household Survey}

An initial rapid assessment was carried out in six villages surrounding the wetland, namely Bagjhan, Purani Motapung, Rangara Te Natungaon, Gotong Gaon, Na-Motapung Gaon, Dhalakhat Gaon, to determine household dependency on wetland resources. The initial assessment showed that about $40 \%$ of the total households were found to depend directly on wetland resources. Among these households, about $10 \%$ were randomly selected for the household survey. Using a semi-structured questionnaire, a total of 101 wetland dependent households were surveyed in these villages. Fifteen to twenty questionnaires were answered per village and answered by the most senior available person of the household. Most of the respondents were males between 20 and 73 years old. The questionnaire was prepared in collaboration with a local organization, Aaranyak, who conducted this field survey during September and October 2013 and again in March 2014. Questions focused on the ecosystem services used, people's dependency on them, drivers of change and their impacts on ecosystem services. The questionnaire is shown in Supplementary materials.

\subsubsection{Focus Group Discussion (FGDs)}

The list of ecosystem services derived from the household survey was validated during focus group discussions. Five focus group discussions (FGD) were carried out at the community level in the first five villages (Table 1) with an average of $8-10$ participants in each group during Sept-Oct 2013. Two more focus group discussions were organized in February 2014 in the Dhalakhat village. The focus group members were selected based on their livelihood strategy and dependency on the wetland Beel. To avoid some of the known problems with focus discussion groups, we kept the size of groups to 8-10 people, used a prepared checklist, ensured all participants were willing to engage in the discussion and used a local moderator. Different drivers of change and people's dependency on wetlands were also thoroughly discussed among the groups. The listed ecosystem services were also ranked during discussions. 


\subsubsection{Stakeholder Workshops}

Two stakeholder workshops were organized, one at the local level and one at the district level, in Tinsukiya district in February and October 2013, respectively. The district-level workshop participants included local university teachers, NGO representatives, government representatives, and members of civil society organizations whereas the local-level workshop included village leaders, members of community groups, and hotel owners. The aim of these workshops was to understand perceptions of local stakeholders with respect to drivers of change of the wetland, and gather suggestions for sustainable conservation and management of wetland resources. The key questions discussed in these workshop included, but were not limited to, (a) what is the present status of the wetland in terms of availability of ecosystem services, (b) what are the key ecosystem services that local communities are deriving from the wetland, (c) what are the trends in changes of ecosystem services availability, (d) what are the major drivers of change, and (e) what management prescriptions are required to manage the wetland?

\subsubsection{Key Informant Interviews}

Representatives of the government authorities, including forest officials and the district commissioner, as well as NGOs, research institutes, civil society organizations, and other organizations were also consulted for listing of ecosystem services of the wetland during October 2014 to February 2015. The key questions asked during interviews focused on livelihood strategies and drivers of change in the wetland. A total of 20 representatives from various organizations were consulted as key informants during the study to help us understand the patterns of change and the drivers. Criteria for selection of the key informants were their knowledge about the wetland resources and people's dependency and involvement in the management of the wetland.

\subsection{Data Analysis}

The quantitative data were analyzed using frequency analysis with Statistical Package for Social Sciences (SPSS) 15.0 software to determine local people's dependency and the impacts of different drivers on the wetland ecosystem. Qualitative data obtained from interviews were first coded and categorized into themes according to the research questions (i.e., ecosystem services; drivers of change, livelihoods strategy etc.) and similar coded themes were grouped together. Ecosystem services ranking was performed using participatory tools. Participants of focus group discussions and workshop were asked to identify key ecosystems available from the wetlands. Once key ecosystem services were listed, participants were asked to rank the listed ecosystem services on a scale of 1 to 10 ( 1 with least preference and 10 with the highest). The overall ranking was based on the total marks for each ecosystem service divided by number of respondents. Similarly, drivers of ecosystem change were identified through both qualitative analysis (focus group discussion, workshop) and also derived from household questionnaires.

\section{Results}

The population of Maguri-Motapung wetland is dominated by ethnic minorities such as Morang, Motok, Kuch with an average households size of 4.9 . The literacy rate is $62 \%$ with less than $5 \%$ of the population is above higher secondary education. The average landholding is about half a hectare. Livestock farming, agriculture and fishing are the key livelihood options with less than $10 \%$ of the population involved in government employment or with a private salaried position.

\subsection{Ecosystem Services, Their Use and Ranking}

A total of 29 key ecosystem services were identified through household survey, FGDs and key informants interviews for the Maguri-Motapung Beel. Among them, 15 were provisioning, seven regulating, two supporting and five were cultural services (Table 2). 
Table 2. List of ecosystem services identified in the study area. Source: Household survey, 2013, Focus group discussions and stakeholders workshop.

\begin{tabular}{cc}
\hline Ecosystem Services Category & Ecosystem Service Recorded \\
\hline Provisioning (15) & $\begin{array}{c}\text { Timber, thatch, bamboo, fuelwood, fish, livestock grazing, } \\
\text { edible plants, medicine, macrophytes, NTFPs, Germplasm, } \\
\text { water for drinking, irrigation, fodder, hunting }\end{array}$ \\
& $\begin{array}{c}\text { Climate regulation, air purification, nutrient cycling, flood } \\
\text { control, pollination, siltation control, water regulation } \\
\text { (used for irrigation and drinking) }\end{array}$ \\
Regulating (7) & $\begin{array}{c}\text { Tourism, educational and research, recreational visit, } \\
\text { bird watching, spiritual/inspirational value }\end{array}$ \\
Cultural (5) & Habitat for wild flora and fauna, Nursery for fishes \\
\hline
\end{tabular}

During focus group discussions with local communities, the top ranked service was fishing followed by tourism, habitats for biodiversity, livestock grazing, and fuel wood collection. Seven out of 10 were provisioning services, while two were supporting services and one was a cultural service. These services were ranked based on their use at their household and/or ability to sell them in the market for economic returns. The top 10 services with details on their use by local people are given in Table 3.

Table 3. Ecosystem services, their use and ranking by local communities (Lower number indicates higher preference). Source: Focus Group Discussion, 2013.

\begin{tabular}{|c|c|c|c|}
\hline Ecosystem Services & Use & Ranking & Remarks \\
\hline Fish (provisioning) & $\begin{array}{l}\text { Food and selling in } \\
\text { the market }\end{array}$ & 1 & $\begin{array}{l}117 \text { Fishermen ( } 20 \text { groups) from four villages are } \\
\text { dependent on Maguri beel. An average of IRs } 1000 \text { fish } \\
\text { catch per week per group }\end{array}$ \\
\hline Tourism (cultural) & $\begin{array}{l}\text { Employment as } \\
\text { guides or hotel } \\
\text { employees }\end{array}$ & 2 & $\begin{array}{l}\text { Important tourist destination. An estimated 20,000 } \\
\text { tourists visit per year }\end{array}$ \\
\hline $\begin{array}{l}\text { Habitat for } \\
\text { biodiversity } \\
\text { (supporting) }\end{array}$ & $\begin{array}{l}\text { Supporting } \\
\text { biodiversity of } \\
\text { global significance }\end{array}$ & 3 & $\begin{array}{l}\text { Regarded as an important habitat for wild flora and } \\
\text { fauna by local communities }\end{array}$ \\
\hline $\begin{array}{l}\text { Fuelwood } \\
\text { (provisioning) }\end{array}$ & $\begin{array}{l}\text { Cooking and } \\
\text { heating }\end{array}$ & 4 & $\begin{array}{l}\text { One bicycle-load of fuelwood sold at the rate of INR. } \\
\qquad 500-700 \text { (USD } 1=\sim \text { INR } 66)\end{array}$ \\
\hline $\begin{array}{l}\text { Nursery for fishes } \\
\text { (supporting) }\end{array}$ & $\begin{array}{l}\text { Breeding ground } \\
\text { for fish }\end{array}$ & 5 & High diversity of fish in the beel \\
\hline $\begin{array}{l}\text { Livestock grazing } \\
\text { (provisioning) }\end{array}$ & $\begin{array}{l}\text { Use by local } \\
\text { communities }\end{array}$ & 6 & $\begin{array}{c}\text { Livestock is one of the major livelihood strategies in } \\
\text { the area }\end{array}$ \\
\hline Water (provisioning) & $\begin{array}{l}\text { An important } \\
\text { source for } \\
\text { irrigating } \\
\text { agriculture land }\end{array}$ & 7 & \\
\hline $\begin{array}{l}\text { Edible plants } \\
\text { (provisioning) }\end{array}$ & $\begin{array}{l}\text { Collection for } \\
\text { household use and } \\
\text { selling in the } \\
\text { market }\end{array}$ & 8 & e.g., Bamboo shoots \\
\hline $\begin{array}{l}\text { Wild animals } \\
\text { (provisioning) }\end{array}$ & $\begin{array}{l}\text { Hunting of wild } \\
\text { animals for food }\end{array}$ & 9 & $\begin{array}{l}\text { e.g., Birds such as Titra, Kalij (local names), and } \\
\text { barking deer are hunted illegally }\end{array}$ \\
\hline $\begin{array}{l}\text { Grass collection } \\
\text { (provisioning) }\end{array}$ & $\begin{array}{l}\text { Used for roofing, or } \\
\text { weaving mats and } \\
\text { sold in the market }\end{array}$ & 10 & $\begin{array}{l}\text { Fiber grass is heavily collected for selling: the market } \\
\text { rate of IRs } 10 \text { per kilogram; also used for mat weaving }\end{array}$ \\
\hline
\end{tabular}

\subsection{People's Dependency on Ecosystem Services}

A total of eight livelihood strategies were revealed. About $84 \%$ of the respondents were involved in fishing and agriculture, while others were involved in teaching, business and labor. Approximately $51 \%$ of the total households are dependent on fishing as their primary occupation (Figure 2). A total of 87 respondents collected 44,783 kilograms (kg) of fish in 2012, earning 7,786,195 Indian Rupees (INR) 
(with 130-250 INR per kg). During the FGDs, an additional 117 fishermen belonging to 20 groups from surrounding villages were reported to depend on fishing, earning an average of 1000 INR per week per group in 2012. Agriculture, including horticulture and homestead tea cultivation, was found to be the second most important livelihood strategy. Locals were also found to cultivate seasonal crops during the dry season on exposed soil tracts of the wetland. Besides these, tourism, business (boat services, small scale hotels), labor, and teaching (government service) were other livelihood strategies found in the area (Figure 2). Tourism employment, such as guiding for bird watching and boat services, is an emerging alternative livelihood option among the young.

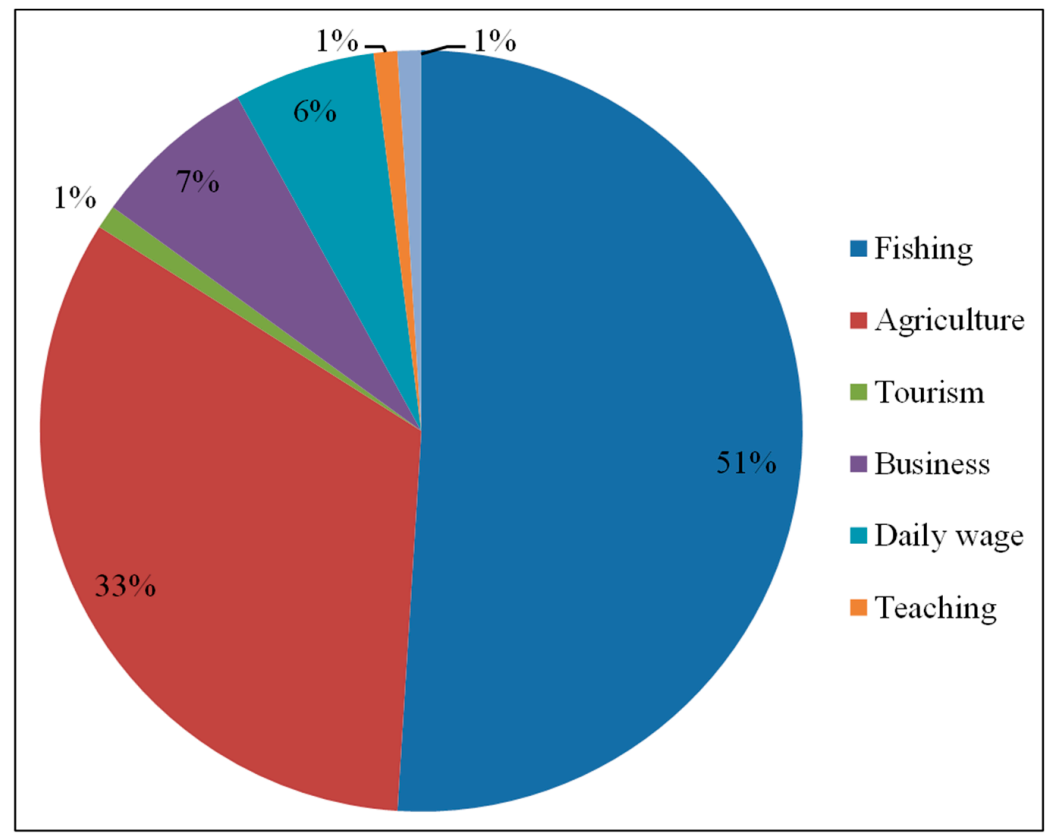

Figure 2. Livelihood strategies of the locals in the Maguri-Motapung Beel.

Of seven identified livelihood strategies, five were directly linked to ecosystem services: fishing, agriculture, livestock grazing, tourism and business such as hotels, guides and boat services were completely dependent on services provided by the Beel (Figure 3).

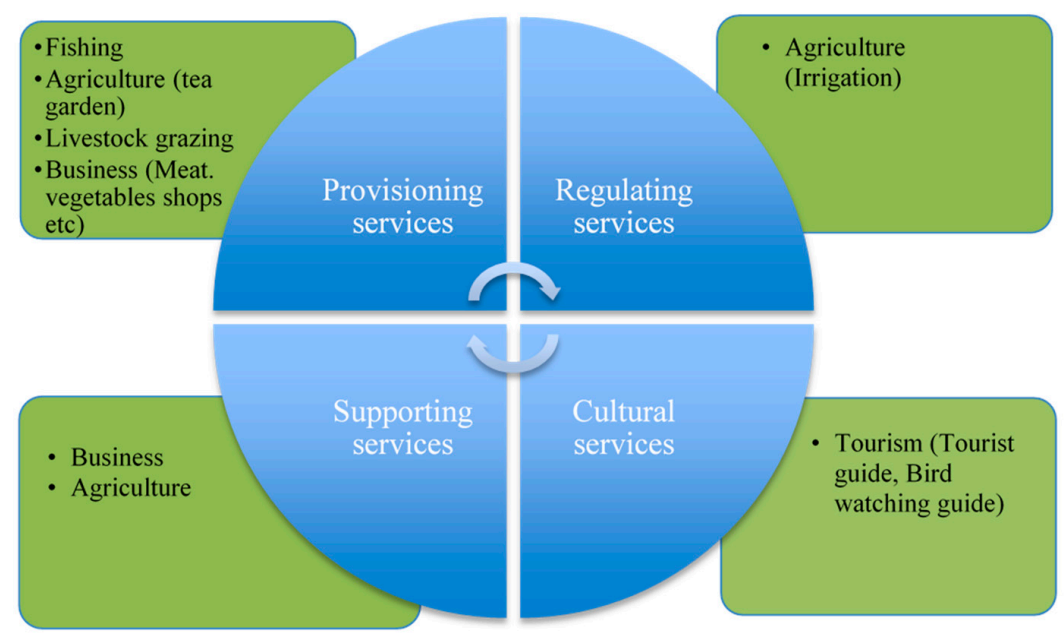

Figure 3. Livelihood strategies and their links to four categories of ecosystem services in Maguri-Motapung Beel (adapted from Sandhu and Sandhu, 2014). 


\subsection{Drivers of Change}

The analysis of household surveys, focus group discussions and community workshops revealed eight direct and three indirect drivers of change in ecosystem services. These drivers of change were both natural and human induced (Table 4). The lack of a wetland management plan, population growth and market were reported as indirect drivers of change. Invasive species, siltation, encroachment, unmanaged tourism, sewage, over exploitation, fish poisoning and deforestation in surrounding areas were reported as direct drivers of change threatening the wetland ecosystem. During the discussions, illegal use of undersized mesh (less than $12 \mathrm{~mm}$ ), mosquito nets (use for catching small and juvenile fishes) and illegal gear in contravention of the Assam Fisheries Rules 1953, fishing during the breeding season (May-July) and catching of gravid and juvenile fish resulting in the depletion of fish stocks were also reported.

Table 4. Drivers of change in Maguri-Motapung Beel Wetland of Assam.

\begin{tabular}{lcc}
\hline Drivers of Change & Direct/Indirect & Natural/Human Induced \\
\hline $\begin{array}{l}\text { Market forces (fuelwood collection, over collection of fish) } \\
\text { Lack of a management plan }\end{array}$ & Indirect & Human induced \\
$\begin{array}{l}\text { Population growth } \\
\text { Invasive species especially Eupatorium and Lantana across the } \\
\text { wetland posing direct threats to natural forest regeneration }\end{array}$ & Indirect & Human induced \\
Siltation due to high flash flood and river cutting & Human induced \\
$\begin{array}{l}\text { Encroachment and illegal agriculture farming is considerable } \\
\text { Unmanaged tourism. e.g., Excessive use of motor boats }\end{array}$ & Direct & Natural/Human induced \\
causing water and sound pollution in the area & Direct & Natural \\
$\begin{array}{l}\text { Sewage and water contamination. e.g., Use of pesticides in } \\
\text { tea garden and its bleaching of the wetland }\end{array}$ & Direct & Human induced \\
$\begin{array}{l}\text { Over exploitation } \\
\text { Fish poisoning }\end{array}$ & Direct & Human induced \\
Deforestation & Direct & Human induced \\
\hline
\end{tabular}

Siltation (94\% of respondents) and over-exploitation of fish (87\%) were found to be the major threats followed by sewage outfall and pollution (56\%), river cutting (bank erosion) $(35 \%)$ and deforestation $(9 \%)$ as direct drivers of change (Figure 4$)$.

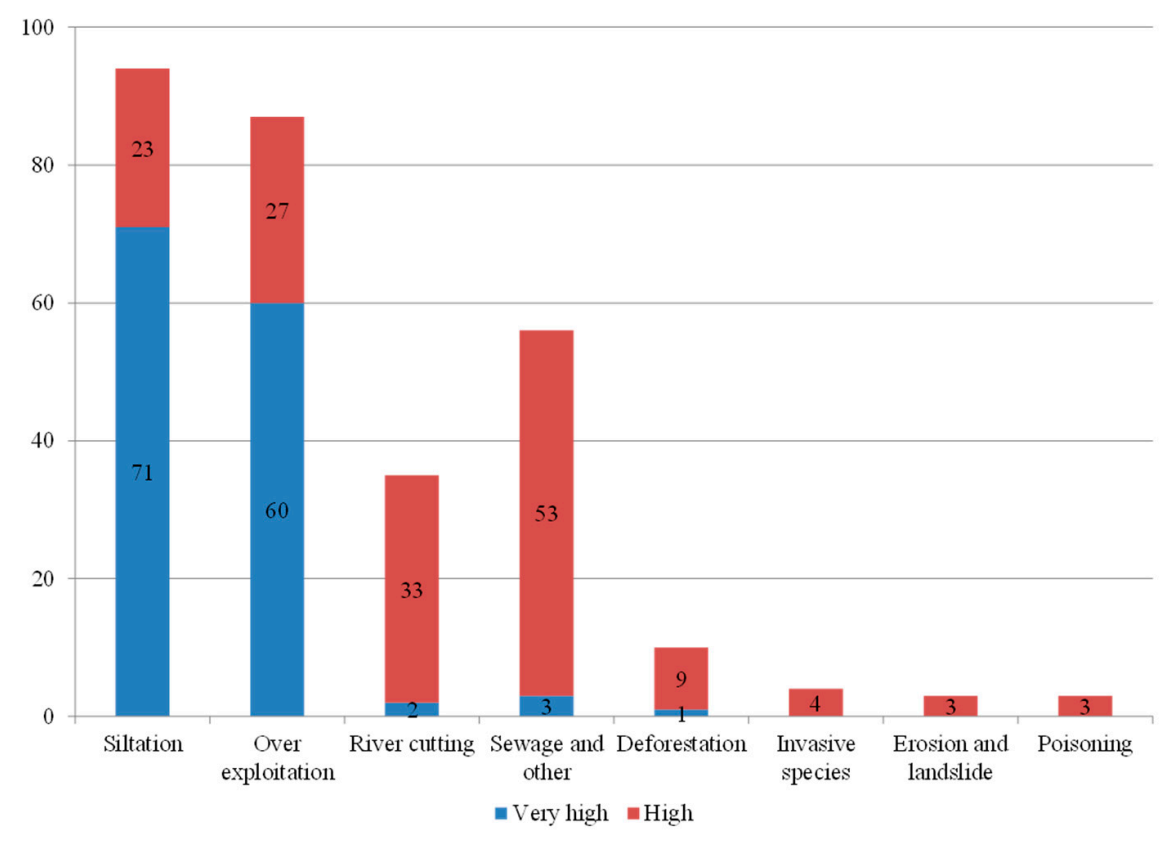

Figure 4. Direct drivers of change through household surveys. 


\subsection{Impacts on Ecosystem Services and People's Dependency}

Both direct and indirect drivers of change were found to impact ecosystem services and people's dependency on the ecosystems in the area. About $98 \%$ of the household survey respondents reported a decrease in availability of material for thatch/bamboo, while $89 \%$ reported a decrease in flood control. About $86 \%$ reported a decline in fish stocks, and a decrease in tourism of $75 \%$ and fodder of $66 \%$. As ecosystem services were directly related to the people's livelihood strategies, changes in ecosystem services showed impacts on people's dependency especially in fishing and agriculture (Figure 5). Although only $13 \%$ reported a decrease in irrigation water, about $42 \%$ reported negative impacts on their agricultural outputs (Figure 5).

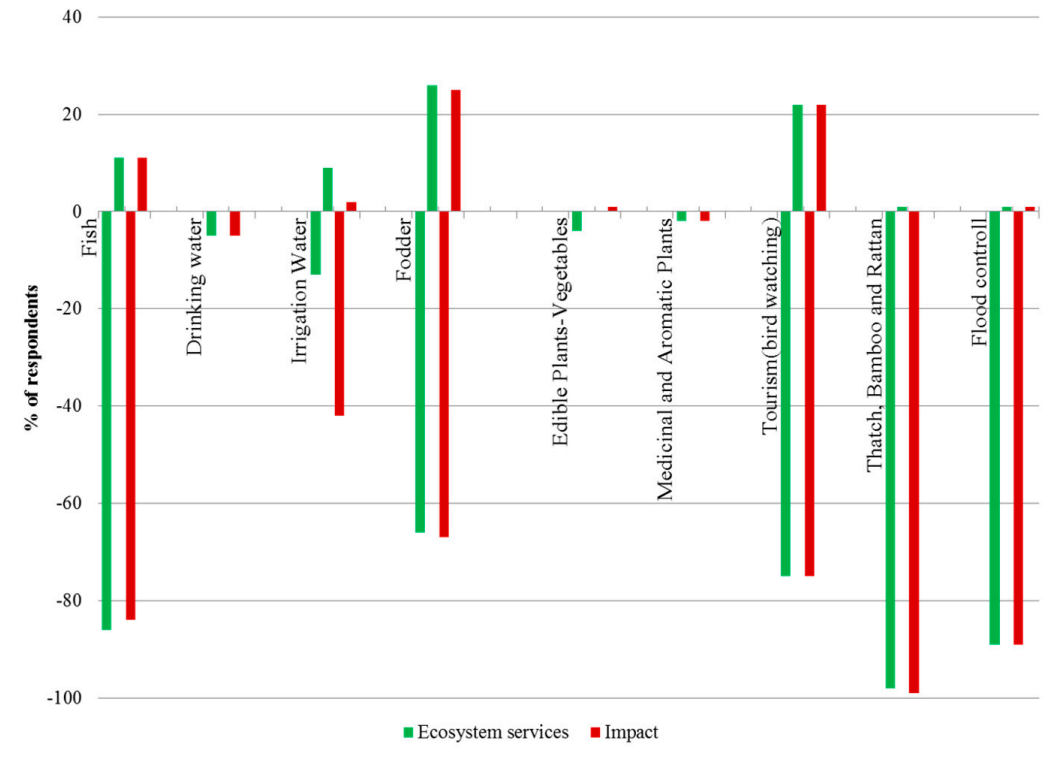

Figure 5. Impacts on ecosystem services derived through household surveys.

Over-exploitation was reported as one of the major reasons for a $57 \%$ decline in fish stock, $50 \%$ in tourism, and a $24 \%$ decrease in thatch/bamboo/rattan collection (Figure 6). Similarly, siltation was reported to negatively impact flood control by $68 \%$, fish production by $42 \%$, fodder collection by $38 \%$ and bamboo/thatch/rattan collection by $37 \%$. Flooding was reported as a natural driver of change that negatively impacted people's livelihoods, by causing a decrease in fodder by $40 \%$ and thatch/bamboo/rattan production and collection by $58 \%$.

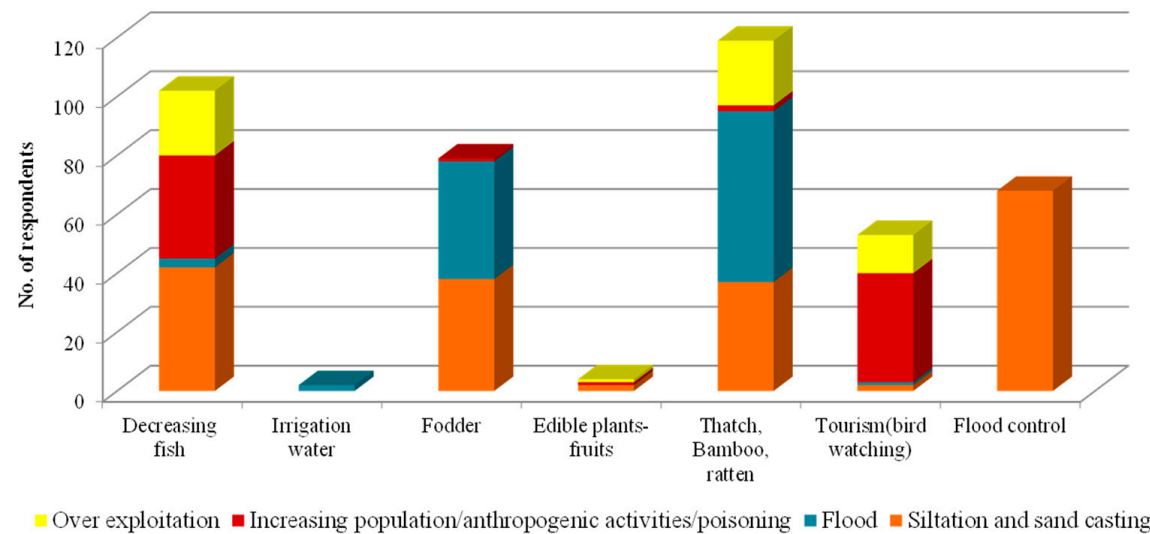

Figure 6. Linkages between drivers of change and changes in availability of ecosystem services, derived through household surveys. 


\section{Discussion}

This study assessed the ecosystem services of a wetland by considering community perceptions based on their dependency on those services. We found 29 ecosystem services, which were reported as important for the livelihoods of local people. The key ecosystem services identified by the locals are provisioning services as they could get immediate returns either in cash or use. Similar results were found for rural communities in Central Romania as noted by Hartel [51]. Human dependence on provisioning services is widely acknowledged, especially in developing countries, as people are highly dependent on natural resource [21,22].

Local people were found to be highly dependent on the listed ecosystem services, as five out of seven livelihood strategies reported from the area are sourced from ecosystem services provided by the wetland, showing the high contribution of ecosystem services of wetland to their livelihoods. High dependency of some local communities on wetland ecosystem services has been reported elsewhere, for example in the Koshi Tappu Wildlife Reserve of Eastern Nepal [52,53] and Kratie province of Cambodia [54]. While all ecosystem services are important for rural livelihoods, fishing, tourism, particularly those based on bird watching, and fuel wood are major ecosystem services on which the wetland community depends. Perceived declining trends in the availability or supply of these services, as previously reported elsewhere [22], threaten the livelihoods of local communities. Further decline of ecosystem services could negatively impact the livelihoods of wetland-dependent communities as they have limited alternative options for livelihood diversification. The vulnerability of wetland communities to such rapid changes in the supply of key ecosystem services is of concern elsewhere, e.g., Bhatta et al. (2015) [22], who showed similar poor communities in the montane parts of Nepal are too poor to adapt their livelihoods to climate-driven rapid changes in ecosystem service supply. What is notable is that the drivers of change, climate change in the montane community and poor management and over use of resources in the wetland, are completely different. However, that poor people are often least able to adapt their livelihoods in the face of such changes has the same result.

The main indirect driver of change was perceived to be the lack of a management plan. Urgent action is required from government and local NGOs to address this concern. The use of illegal fishing nets and fishing during the fish-breeding season clearly indicates that the implementation and monitoring of national laws are weak but also underlines the people's dependency on these wetland resources. Our study demonstrates the weak institutional structure and limited livelihood strategy options available to people in the area. Inadequate institutional arrangements are often regarded as drivers of environmental change [55]. Our results support those studies emphasizing the political and institutional factors involved in the degradation of ecosystems, [13,43]. A holistic management plan for the wetlands with participatory options and approaches and multisectoral investment might help communities to reduce their high dependency on wetland resources, which ultimately should result in increases in the flow of ecosystem services. This will also reduce pressure on the wetland ecosystems and hence the ecosystem services.

Direct drivers such siltation and invasive species cited as damaging this wetland have also been reported as key drivers elsewhere in wetlands in Asia and Africa [43,56,57]. The overexploitation of wetland resources has also been reported by [58]. Our results on ecosystem services and drivers of change in the study wetland are amongst the first for wetland areas in Asia and are therefore an important indication of the state of ecosystem services in wetland areas of this region. Although this study did not specifically focus on biodiversity, the potential impacts of change on the rich biodiversity of the area are obvious. There is an urgent need to plan actions for conserving the area and reducing the direct pressures on the wetland. Providing livelihood options such as aquaculture, small-scale nature-based enterprises and promoting ecotourism in the area might help reduce the direct pressures. 


\section{Conclusions}

In this case study, we argue that the Maguri-Motapung Beel is an important wetland ecosystem providing diverse ecosystem services, especially fish, wetland products and tourism to local communities for their livelihoods. There are a number of direct and indirect drivers negatively impacting the availability of such services, thus impacting the livelihoods of the people. While overexploitation and siltation were identified by the people as the major issues resulting in the degradation of the wetland, the weak implementation of national laws and the lack of a management plan for the area are important factors contributing to the wetland's degradation. An integrated and holistic management plan with alternative livelihood options could be effective in mitigating degradation of the wetlands while maintaining the supply of ecosystem services. Attention should also be paid to the indirect drivers of changes. For instance, analyzing the socio-political and economic drivers of changes to the wetland in the area should be the focus of further research in the area. The similar nature of the results in this study to those previously reported highlights the high dependency of those people surrounding wetlands on the ecosystem services they provide and we should be concerned about the maintenance of wetlands worldwide.

Supplementary Materials: The following are available online at http://www.mdpi.com/2073-445X/5/2/15/s1, Household Questionnaire.

Acknowledgments: This study was a part of the Himalayan Climate Change Adaptation Programme (HICAP). HICAP was implemented jointly by ICIMOD, CICERO and Grid-Arendal in collaboration with local partners and is funded by the Ministry of Foreign Affairs, Norway and the Swedish International Development Agency (SIDA). The views and interpretations in this publication are those of the author(s). We thank Bhaskar Jyoti Bora and Abdul Motaleb for their assistance with the field data collection and community level focus group discussion. We acknowledge the support received from Arup Das for helping us with GIS mapping. We also thank M.S.R. Murthy, and Nand Kishor Agrawal for their valuable feedback on the design of the study, and their comments on an earlier version of the manuscript. We thank four anonymous reviewers for comments that helped improve the manuscript.

Author Contributions: Laxmi D Bhatta was responsible for overall coordination of the study, data collection and finalising the manuscript. Sunita Chaudhary prepared the first draft manuscript with analysis of some field data and Anju Pandit analyzed most of the data from the field and drafted the field report. All co-authors worked collaboratively and contributed to discuss and finalize the manuscript.

Conflicts of Interest: The authors declare no conflict of interest.

\section{References}

1. Mitsch, W.J.; Gosselink, J.G. Wetland, 4th ed.; Wiley: New York, NY, USA, 2007.

2. Ramsar Convention Secretariat (RCS). Wise use of wetlands: A conceptual framework for the wise use of wetlands. In Ramsar Handbooks for the Wise Use of Wetlands, 3rd ed.; RCS: Gland, Switzerland, 2007; pp. 8-9.

3. Keddy, P.A.; Fraser, L.H.; Solomeshch, A.I.; Junk, W.J.; Campbell, D.R.; Arroyo, M.T.K.; Alho, C.J.R. Wet and wonderful: The world's largest wetlands are conservation priorities. BioScience 2009, 59, 39-51. [CrossRef]

4. Cohen-Shacham, E.; Dayan, T.; de Groot, R.; Beltrame, C.; Guillet, F.; Feitelson, E. Using the ecosystem services concept to analyse stakeholder involvement in wetland management. Wetl. Ecol. Manag. 2015, 23, 241-256. [CrossRef]

5. Keddy, P.A. Wetland Ecology: Principles and Conservation; Cambridge University Press: Cambridge, UK, 2000.

6. Gosselink, J.G.; Turner, R.E. The role of dydrology in freshwater ecosystems. In Freshwater Wetlands. Ecological Processes and Management Potential; Good, R.E., Whigham, D.F., Simpson, L.R., Eds.; Academic Press: New York, NY, USA, 1978; pp. 63-78.

7. Mitsch, W.J.; Gosselink, J.G. The value of wetlands: Importance of scale and landscape setting. Ecol. Econ. 2000, 35, 25-33. [CrossRef]

8. Ricaurte, L.F.; Wantzen, K.M.; Agudelo, E.; Betancourt, B.; Jokela, J. Participatory rural appraisal of ecosystem services of wetlands in the Amazonian Piedmont of Colombia: Elements for a sustainable management concept. Wetl. Ecol. Manag. 2014, 22, 343-361. [CrossRef]

9. Schuyt, K. Economic consequences of wetland degradation for local populations in Africa. Ecol. Econ. 2005, 53, 177-190. [CrossRef] 
10. Rebelo, L.M.; McCartney, M.P.; Finlayson, C.M. Wetlands of sub-Saharan Africa: Distribution and contribution of agriculture to livelihoods. Wetl. Ecol. Manag. 2009, 18, 557-555. [CrossRef]

11. Schuyt, K.; Brander, L. Living Waters: Conserving the Source of Life: The Economic Values of the World's Wetlands; WWF: Gland, Switzerland, 2004.

12. Wei, Q.; Tong, L.; Gondwe, J.; Lv, X.; Tong, W.; Liu, Y. Non-use value trends analysis of wetland ecosystem in the Sanjiang Plain, Northeast China. Wetl. Ecol. Manag. 2015, 23, 347-355. [CrossRef]

13. Millennium Ecosystem Assessment. Ecosystems and Human Well-Being: Synthesis; Island Press: Washington, DC, USA, 2005.

14. OECD/IUCN. Guideline for Aid Agencies for Improved Conservation and Sustainable Use of Tropical and Sub-Tropical Wetlands; OECD: Paris, France, 1992.

15. ICSU-UNESCO-UNU. Ecosystem Change and Human Well-being: Research and Monitoring Priorities Based on the Millennium Ecosystem Assessment; International Council for Science: Paris, France, 2008.

16. McAllister, D.E.; Craig, J.F.; Davidson, N.; Delany, S.; Seddon, M. Biodiversity Impacts of Large Dams; Background Paper No.1.; Prepared for IUCN/UNEP/WCD: Gland, Switzerland, 2001.

17. Chaudhary, S.; McGregor, A.; Houston, D.; Chettri, N. The evolution of ecosystem services: A time series and discourse-centered analysis. Environ. Sci. Policy 2015, 54, 25-34. [CrossRef]

18. Bastian, O.; Grunewald, K.; Syrbe, R.U.; Walz, U.; Wende, W. Landscape services: The concept and its practical relevance. Landsc. Ecol. 2014, 10, 1-17. [CrossRef]

19. Brown, K.; Daw, T.; Rosendo, S.; Bunce, M.; Cherrett, N. Ecosystem Services for Poverty Alleviation: Marine $\mathcal{E}$ Coastal Situational Analysis; Synthesis Report; Report for NERC/DFID: London, UK, 2008.

20. Grêt-Regamey, A.; Brunner, S.H.; Kienast, F. Mountain ecosystem services: Who cares? Mt. Res. Dev. 2012, 32, 23-34. [CrossRef]

21. Van Oort, B.V.; Bhatta, L.D.; Baral, H.; Rai, R.K.; Dhakal, M.; Rucevska, I.; Adhikari, R. Assessing community values to support mapping of ecosystem services in the Koshi river basin, Nepal. Ecosyst. Serv. 2015, 13, 70-80. [CrossRef]

22. Bhatta, L.D.; van Oort, B.E.H.; Stork, N.E.; Baral, H. Ecosystem services and livelihoods in a changing climate: Understanding local adaptations in the Upper Koshi, Nepal. Int. J. Biodivers. Sci. Ecosyst. Serv. Manag. 2015, 11, 145-155. [CrossRef]

23. Baral, H.; Keenan, R.J.; Fox, J.C.; Stork, N.E.; Kasel, S. Spatial assessment of ecosystem goods and services in complex production landscapes: A case study from south-eastern Australia. Ecol. Complex. 2013, 13, 35-45. [CrossRef]

24. Paudyal, K.; Baral, H.; Burkhard, B.; Bhandari, S.P.; Keenan, R.J. Participatory assessment and mapping of ecosystem services in a data-poor region: Case study of community-managed forests in central Nepal. Ecol. Serv. 2015, 13, 81-92. [CrossRef]

25. Baral, H.; Keenan, R.J.; Stork, N.E.; Kasel, S. Measuring and managing ecosystem goods and services in changing landscapes: A south-east Australian perspective. J. Environ. Plan. Manag. 2014, 57, 961-983. [CrossRef]

26. Wu, J. Landscape sustainability science: Ecosystem services and human well-being in changing landscapes. Landsc. Ecol. 2013, 28, 999-1023. [CrossRef]

27. Daily, G.C.; Polasky, S.; Goldstein, J.; Kareiva, P.M.; Mooney, H.A.; Pejchar, L.; Ricketts, T.H.; Salzman, J.; Shallenberger, R. Ecosystem services in decision making: Time to deliver. Front. Ecol. Environ. 2009, 7, 21-28. [CrossRef]

28. Costanza, R. Nature: Ecosystems without commodifying them. Nature 2006, 443, 749. [CrossRef] [PubMed]

29. Malinga, R.; Gordon, L.J.; Lindborg, R.; Jewitt, G. Using participatory scenario planning to identify ecosystem services in changing landscapes. Ecol. Soc. 2013, 18, 10. [CrossRef]

30. Gopal, B.; Wolfgang, J.; Junk, C.M.; Finlayson, C.; Breen, C.M. Present state and future of tropical wetlands'. In Aquatic Ecosystems; Polunin, N., Ed.; Cambridge University Press, for the Foundation for Environmental Conservation: Cambridge, UK, 2008; pp. 141-154.

31. Bassi, N.; Kumar, M.D.; Sharma, A.; Pardh-Saradhi, P. Status of wetlands in India: A review of extent, ecosystem benefits, threats and management strategies. J. Hydrol. 2014, 2, 1-19. [CrossRef]

32. Space Application Center (SAC). National Wetland Atlas; SAC, Indian Space Research Organization: Ahemdabad, India, 2011. 
33. Prasad, S.N.; Ramachandra, T.V.; Ahalya, N.; Sengupta, T.; Kumar, A.; Tiwari, A.K.; Vijayan, V.S.; Vijayan, L. Conservation of wetlands of India-A review. Trop. Ecol. 2002, 43, 173-186.

34. Deepa, R.S.; Ramachandra, T.V. Impact of urbanization in the interconnectivity of wetlands. In Proceedings of the National Symposium on Remote Sensing Applications for Natural Resources: Retrospective and Perspective (XIX-XXI 1999), Indian Society of Remote Sensing, Banglore, India, 19-21 January 1999.

35. Chong, J. Protective Values of Mangroves and Coral Ecosystem: A Review of Methods and Evidence; IUCN: Gland, Switzerland, 2005.

36. Gopal, B. Future of wetlands in tropical and subtropical Asia, especially in the face of climate change. Aquat. Sci. 2013, 75, 39-61. [CrossRef]

37. Syphard, A.D.; Garcia, M.W. Human and beaver induced wetland changes in the Chickahominy River watershed from 1953 to 1994. Wetlands 2001, 21, 342-353. [CrossRef]

38. Vijayan, V.S.; Prasad, S.N.; Vijayan, L.; Muralidharan, S. Inland Wetlands of India: Conservation Priorities; Sálim Ali Centre for Ornithology and Natural History: Coimbatore, India, 2004.

39. World Wide Fund for Nature (WWF); Asian Wetland Burea (AWB). Directory of Indian Wetlands; World Wide Fund for Nature: New Delhi, India; Asian Wetland Burea: Kuala Lumpur, Malaysia, 1993.

40. Balmford, A.; Bruner, A.; Cooper, P.; Costanza, R.; Farber, S.; Green, R.; Jenkins, M.; Jefferiss, P.; Jessamay, V.; Madden, J.; et al. Economic reasons for conserving wild nature. Science 2011, 297, 950-953. [CrossRef] [PubMed]

41. Mmopelwa, G.; Blignaut, J.N. The Okavango Delta: The value of tourism. S. Afr. J. Econ. Manag. Sci. 2006, 9, 113-127.

42. Ostrom, E.; Janssen, M.A.; Anderies, J.M. Going beyond panaceas. Proc. Natl. Acad. Sci. USA 2007, 104, 15176-15178. [CrossRef] [PubMed]

43. Adekola, O.; Mitchell, G. The Niger Delta wetlands: Threats to ecosystem services, their importance to dependent communities and possible management measures. Int. J. Biodivers. Sci. Ecosyst. Serv. Manag. 2011, 7, 50-68. [CrossRef]

44. Das, P.; Joshi, S.; Rout, J.; Upreti, D.K. Impact of anthropogenic factors on abundance variability among lichen species in southern Assam, North East India. Trop. Ecol. 2013, 54, 67-72.

45. Bania, R. Hydrobiology in Relation to Fishery with Special Reference to Socio-Economics of Fisher Folk in and around Dibru-Saikhowa National Park, Assam. Ph.D. Thesis, Dibrugarh University, Dibrugarh, India, 2011.

46. Myers, N.; Mittermeier, R.; Mittermeier, C.; da Fonseca, G.; Kent, J. Biodiversity hotspots for conservation priorities. Nature 2000, 403, 853-858. [CrossRef] [PubMed]

47. Bania, R.; Biswas, S.P. Fish based ecotourism in Dibru-Saikhowa National Park. In Proceeding of the National Seminar on Biodiversity of the North-East with special Reference to the Brahmaputra Valley, Kamalabari, India, 26 April 2012.

48. Borgohain, A.; Bania, R. Potentiality for promoting fish based ecotourism for sustainable development. In Strategy for Developing Fisheries in Flood Affected Areas of Assam; Borah, B.C., Bhattacharyya, H.C., Eds.; Assam Agricultural University: Jorhat, India, 2013; pp. 112-127.

49. Stattersfield, A.J.; Crosby, M.J.; Long, A.J.; Wege, D.C. Endemic Bird Areas of the World: Priorities for Biodiversity Conservation; Bird Life International: Cambridge, UK, 1998.

50. Sandhu, H.; Sandhu, S. Poverty, development and Himalayan ecosystems. Ambio 2015, 44, $297-307$. [CrossRef] [PubMed]

51. Hartel, T.; Fischer, J.; Campeanu, C.; Milcu, A.I.; Hanspach, J.; Fazey, I. The importance of ecosystem services for rural inhabitants in a changing cultural landscape in Romania. Ecol. Soc. 2014, 19, 42. [CrossRef]

52. Chaudhary, S.; Chettri, N.; Uddin, K.; Khatri, T.B.; Dhakal, M.; Bajracharya, B.; Ning, W. Implications of land cover change on ecosystems, ecosystem services and dependency of people: A case study from the Koshi Tappu Wildlife Reserve, Nepal. J. Inst. For. Nepal 2015, 14, 81-97.

53. ICIMOD; MoFSC. An Integrated Assessment of the Effects of Natural and Human Disturbances on a Wetland Ecosystem: A Retrospective from the Koshi Tappu Wildlife Reserve; ICIMOD: Kathmandu, Nepal, 2014.

54. Persson, L.; Phirun, N.; Ngin, C.; Pilgrim, J.; Sam, C.; Noel, S. Ecosystem Service Supporting Livelihood in Combodia; Project Report-2010; Stockholm Environment Institute: Stockholm, Sweden, 2010.

55. Young, O.R. The Institutional Dimensions of Environmental Change: Fit, Interplay and Scale; MIT Press: Cambridge, MA, USA, 2002. 
56. Eppink, F.V.; Brander, L.M.; Wagtendonk, A.J. An initial assessment of the economic value of coastal and freshwater wetlands in West Asia. Land 2014, 3, 557-573. [CrossRef]

57. Turpie, J.K.; Marais, C.; Blignaut, J.N. The working for water programme: Evolution of a payments for ecosystem services mechanism that addresses both poverty and ecosystem service delivery in South Africa. Ecol. Econ. 2008, 65, 789-799. [CrossRef]

58. Esteller, M.V.; Diaz-Delgado, C. Environmental effects of aquifer overexploitation: A case study in the highlands of Mexico. Environ. Manag. 2002, 29, 266-278. [CrossRef]

(c) 2016 by the authors; licensee MDPI, Basel, Switzerland. This article is an open access article distributed under the terms and conditions of the Creative Commons Attribution (CC-BY) license (http:/ / creativecommons.org/licenses/by/4.0/). 